\title{
Myeloproliferative neoplasiar og JAK2-mutasjonar
}

\begin{abstract}
BAKGRUNN Samanhengen mellom JAK2V617F-mutasjonen og myeloproliferative neoplasiar vart beskriven i 2005 og har etter dette bana veg for ny forståing av desse sjukdomane. Føremålet med studien var å finne førekomsten av JAK2V617F i ein norsk pasientkohort utreda for myeloproliferativ neoplasi samt undersøkje potensielle kliniske og biokjemiske skilnader mellom mutasjonspositive og mutasjonsnegative pasientar.
\end{abstract}

MATERIALE OG METODE Laboratorium for klinisk biokjemi ved Haukeland universitetssjukehus har sidan 2006 gjort analysar av JAK2V617F-mutasjon ved sanntidspolymerasekjedereaksjon (PCR). I denne studien innhenta vi resultat frå alle JAK2V617F-mutasjonsanalysar gjort i perioden 2006-12. Resultata er samanlikna med kliniske opplysningar frå elektronisk pasientjournal.

RESULTAT Av 803 pasientar som fekk utført analysen, fekk 156 påvist mutasjonen $(19,4 \%$ ), medan 216 var diagnostiserte med ein myeloproliferativ tilstand. 81 av 108 pasientar diagnostiserte med polycythaemia vera $(75,0 \%), 55$ av 92 med essensiell trombocytose $(59,8 \%)$ og åtte av 16 pasientar med myelofibrose $(50,0 \%)$ hadde mutasjonen. Mutasjonspositive pasientar med polycythaemia vera hadde auka nivå av blodplater og leukocyttar. Mutasjonsnegative hadde lågare debutalder og var oftare røykare. Mutasjonspositive pasientar med essensiell trombocytose hadde auka nivå av hemoglobin, hematokrit og leukocyttar.

TOLKING JAK2V617F er ein essensiell diagnostisk markør ved myeloproliferative neoplasiar og er assosiert med ulikskapar i fenotype ved desse tilstandane.

Myeloproliferative neoplasiar er ei gruppe tilstandar karakteriserte av klonal vekst i ei eller fleire hematopoetiske cellelinjer. Gruppa inkluderer kronisk myelogen leukemi, polycythaemia vera, essensiell trombocytose og primær myelofibrose. Kronisk myelogen leukemi har eit anna etiologisk opphav enn dei tre andre og er assosiert med ein resiprok translokasjon mellom kromosom 9 og kromosom 22, noko som fører til danning av philadelphiakromosom. Vi skil såleis mellom philadelphiakromosompositive og philadelphiakromosomnegative myeloproliferative neoplasiar.

Tilstandane har ein samla årleg insidens på rundt 2-3/100 $000(1-3)$. Ettersom polycythaemia vera og essensiell trombocytose er lågmaligne $\mathrm{i}$ sin natur, er prevalensen høgare enn insidensen, på rundt 50/100 000 for begge. Myelofibrose er ein meir høgmalign sjukdom med dårlegare prognose $\mathrm{og}$ har ein prevalens på omkring 5/100 000 $(1-4)$.

Sjukdomane karakteriserast av overproduksjon av modne, funksjonelle blodceller, frå ein eller fleire av dei myeloide cellerekkene i beinmargen, ofte også i lever og milt. Det kliniske gangen er langvarig, med trombose- og blødingsrisiko samt tendens til fibroseutvikling og sjeldnare transformasjon til meir høgmaligne blodsjukdomar som myelodysplastisk syndrom og akutt myelogen leukemi (5).

Slektskapen mellom dei philadelphiakro- mosomnegative myeloproliferative sjukdomane atterspeglar seg også i den molekylære patogenesen. Genet JAK2 er lokalisert i posisjon 24 på kromosom 9 og kodar for ein tyrosinkinase som verkar nedstraums for aktivering av cytokinreseptorar (fig 1). Kunnskap om rolla til JAK2 i signalvegar relatert til hematopoese førte til hypotesen om at ein mutasjon i dette genet kunne vere relatert til patogenesen.

I 2005 fann fire uavhengige forskingsgrupper ein somatisk mutasjon i JAK2-genet som førte til ein valin-til-fenylalanin-substitusjon i kodon 617 og dermed auka tyrosinfosforylering og aktivitet gjennom intracellulære signalvegar (6-10). Nomenklaturen er derfor skrive som JAK2V617F, heretter omtala som $J A K 2$-mutasjonen. Mutasjonen gjer at hematopoetiske celler vert meir sensitive for vekstfaktorar som erytropoietin og trombopoietin, med auka proliferasjon i myeloide cellelinjer som resultat. Påvising av $J A K 2$-mutasjonen vart inkludert i dei diagnostiske kriteria til Verdas helseorganisasjon for myeloproliferative neoplasiar i $2008(11,12)$.

Det er tidlegare skildra at pasientar med $J A K 2$-positiv myeloproliferativ tilstand har andre fenotypiske karakteristika enn pasientar med JAK2-negativ sjukdom (13-15). Analyse av JAK2-mutasjonen vart tilgjengeleg i Noreg i 2006. Føremålet med denne studien var å sjå på førekomst av mutasjonen i ei norsk pasientkohort utreda for myelo-

\section{Henry Almedal}

Det medisinsk-odontologiske fakultet Universitetet i Bergen

\section{Marta Vorland}

Laboratorium for klinisk biokjemi Haukeland universitetssjukehus

\section{Aasne K. Aarsand}

Laboratorium for klinisk biokjemi Haukeland universitetssjukehus og

Norsk kvalitetsforbedring av

laboratorievirksomhet utenfor sykehus (NOKLUS), Haraldsplass Diakonale sykehus

\section{Ida-Sofie Grønningsæter}

Medisinsk avdeling

Haukeland universitetssjukehus og

Klinisk institutt 2

Det medisinsk-odontologiske fakultet Universitetet i Bergen

\section{Øystein Bruserud}

Medisinsk avdeling

Haukeland universitetssjukehus

og

Klinisk institutt 2

Det medisinsk-odontologiske fakultet

Universitetet i Bergen

\section{Håkon Reikvam}

hakon.reikvam@med.uib.no

Medisinsk avdeling

Haraldsplass Diakonale sykehus

Tl

Engelsk omsetjing på www.tidsskriftet.no

\section{HOVUDBODSKAP}

Myeloproliferative neoplasiar er karakteriserte av auka produksjon i ei eller fleire myeloide cellerekkjer, ofte assosiert med ein punktmutasjon i JAK2-genet på kromosom 9.

l ein kohort på 803 pasientar undersøkte ved Haukeland universitetssjukehus i perioden 2006-12 fekk $19 \%$ påvist denne mutasjonen

JAK2V617F-positive og JAK2V617F-negative myeloide neoplasiar hadde ulike kliniske og biokjemiske karakteristika

Ein fann ein lågare førekomst av mutasjonen ved polycythaemia vera enn det som er rapportert tidlegare, noko som sannsynleggjer at ikkje alle pasientane ville fylt dagens diagnostiske kriterium for sjukdomen 


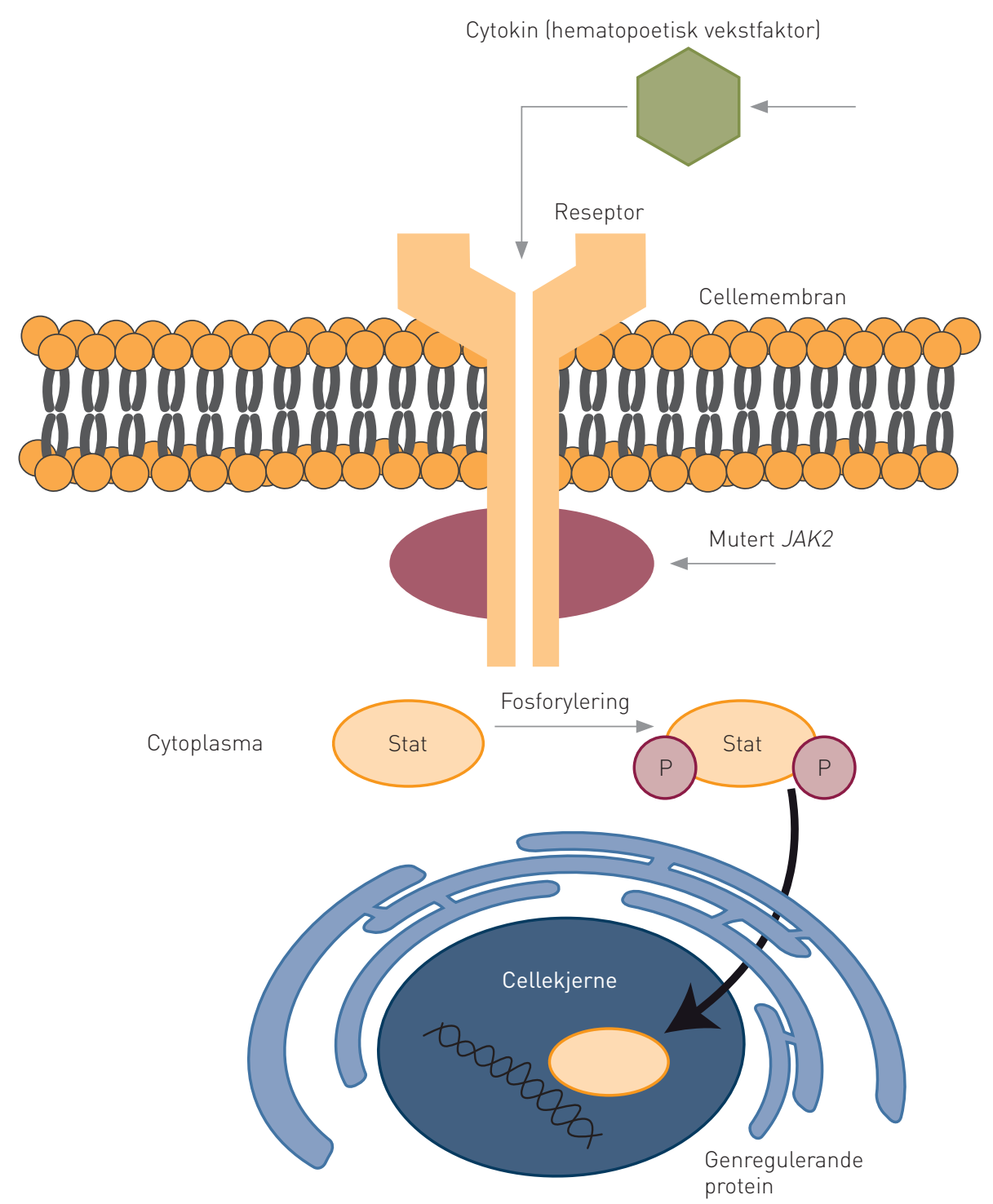

Figur 1 JAK2-signalering. JAK2 er ein kinase uttrykt i hematopoetiske celler som blir stimulert når cytokin eller hematopoetiske vekstfaktorar bind seg til han. Aktivering fører til konformasjonsendring, med påfølgande fosforylering og aktivering av intracellulære signalvegar, spesielt STAT-signalvegen (signaltransduser og aktivator av transkripsjon). I celler med mutert JAK2 er det konstant auka signalering via denne signalvegen, noko som gjev auka celleproduksjon og celledifferensiering av myeloide celler

proliferativ neoplasi samt undersøke om påvising av mutasjonen var karakterisert av spesielle biokjemiske og kliniske kjenneteikn.

\section{Materiale og metode}

Laboratorium for klinisk biokjemi, Haukeland universitetssjukehus, har sidan 2006 tilbydd analyse for $J A K 2$-mutasjonen, utført på DNA isolert frå leukocyttar i fullblod (16). Metoden er basert på ein sanntidspolymerasekjedereaksjon (PCR) (16), og resultat vert rapporterte som allelbyrde (mengde mutert $J A K 2$ av total $J A K 2$ i prosent). Deteksjonsgrensa er på $0,1 \%$, og ved resultat under dette blir pasienten karakterisert som $J A K 2$-negativ. Låg allelbyrde vert definert som ratio $\% 0,1<\in<25$, høg allelbyrde som ratio $\% 25<\epsilon<100$. I perioden 2006-08 vart JAK2-mutasjonsanalysen gjort med ein annan PCR-metode, med deteksjongrense på $2 \%$ (17).

Med godkjenning av den regionale etiske komiteen (REK vest, referansenummer 2011/2278) henta vi inn kliniske opplysningar om pasientar der JAK2-mutasjonsanalysen blei utført i perioden 2006-12. Av dei totalt 1613 registrerte prøvane vart dublettar (same pasient) og prøver frå pasientar utanfor Helse Bergen ikkje tatt med, då kliniske opplysningar berre var tilgjengelege frå elektronisk pasientjournal (DIPS) tilhøyrande Helse Bergen. Den totale studiepopulasjonen vart 803 pasientar.

Innhenta klinisk informasjon omfatta diagnose stilt av behandlande lege og følgjande variablar ved diagnosetidspunktet: alder, mutasjonsstatus, allelbyrde, hematologiske blodprøver, røykestatus og komplikasjonar. Beinmargsbiopsi og eventuelt ytterlegare diagnostisk utgreiing var gjort der behandlande lege meinte det var indisert.

Statistikkprogrammet SPSS15.0 vart brukt til kalkulasjonar og grafisk framstilling. For statistiske analysar vart khikvadrattest, Fishers eksakte test og t-test brukt. P-verdiar $<0,05$ vart rekna som statistisk signifikante.

\section{Resultat}

Diagnostikk av myeloproliferative neoplasier

Av dei 803 pasientane fekk 156 påvist JAK2mutasjonen $(19,4 \%)$. Ut frå opplysningar frå elektronisk pasientjournal hadde 216 blitt diagnostisert med ein myeloproliferativ tilstand. 
Av dei var 144 (66,7\%) JAK2V617F-positive og $72(33,3 \%) J A K 2$ V617F-negative (fig 2).

\section{Diagnostisk fordeling}

Av dei 216 pasientane som var diagnostiserte med myeloproliferativ tilstand, var følgjande diagnosar registrerte: 108 polycythaemia vera $(50,0 \%)$, 92 essensiell trombocytose $(42,6 \%)$ og 16 myelofibrose $(7,4 \%)$.

Fordelinga av påvist $J A K 2$-mutasjon var ulik mellom dei ulike diagnosane (fig 3). 81 av dei 108 pasientane med polycythaemia vera $(75,0 \%), 55$ av dei 92 med essensiell trombocytose $(59,9 \%)$ og åtte av dei 16 med primær myelofibrose $(50,0 \%)$ fekk påvist mutasjonen. Ettersom det var få pasientar som var diagnostisert med myelofibrose, blei ytterlegare analysar berre utført for det øvrige pasientmaterialet.

\section{Biokjemiske og kliniske variablar} ved polycythaemia vera

Hjå pasientar med polycythaemia vera var gjennomsnittleg trombocyttverdi ved diagnosetidspunktet over dobbelt så høg hos mutasjonspositive som hos mutasjonsnegative (tab 1). Verdiane av leukocyttar og laktatdehydrogenase var også signifikant auka hos mutasjonspositive. Vidare var alderen ved diagnosetidspunktet distinkt lågare hjå mutasjonsnegative. Desse var også oftare røykarar enn dei mutasjonspositive.

Kvinner var i overvekt hos dei mutasjonspositive, medan det hjå dei mutasjonsnegative var eit lite mannleg fleirtal. For verdiar av hemoglobin og erytrocyttvolumfraksjon (EVF) var det ingen tydeleg skilnad mellom mutasjonsgruppene. Det vart heller ikkje funne nokon relasjon mellom mutasjonsstatus og førekomst av trombose (tab 2).

\section{Biokjemiske og kliniske variablar}

ved essensiell trombocytose

Hemoglobinnivået ved diagnosetidspunktet var i gjennomsnitt høgare hjå mutasjonspositive enn hjå mutasjonsnegative. Ein fann for dei mutasjonspositive også signifikant auka verdiar av erytrocyttvolumfraksjon og leukocyttar (tab 1). Det var høgare førekomst av arteriell trombose hjå dei mutasjonspositive, men funnet var ikkje statistisk signifikant (tab 2).

For dei resterande variablane var det heller ingen signifikante skilnader mellom subgruppene.

\section{Høg allelbyrde og auka risiko}

for komplikasjonar

Det var registrert opplysningar om allelbyrde for totalt 143 pasientar. 39 av desse $(27 \%)$ hadde høg allelbyrde, medan dei øvrige 104 (73\%) hadde låg.

Vi fann ingen signifikant skilnad i førekomst av tromboser mellom desse gruppene,

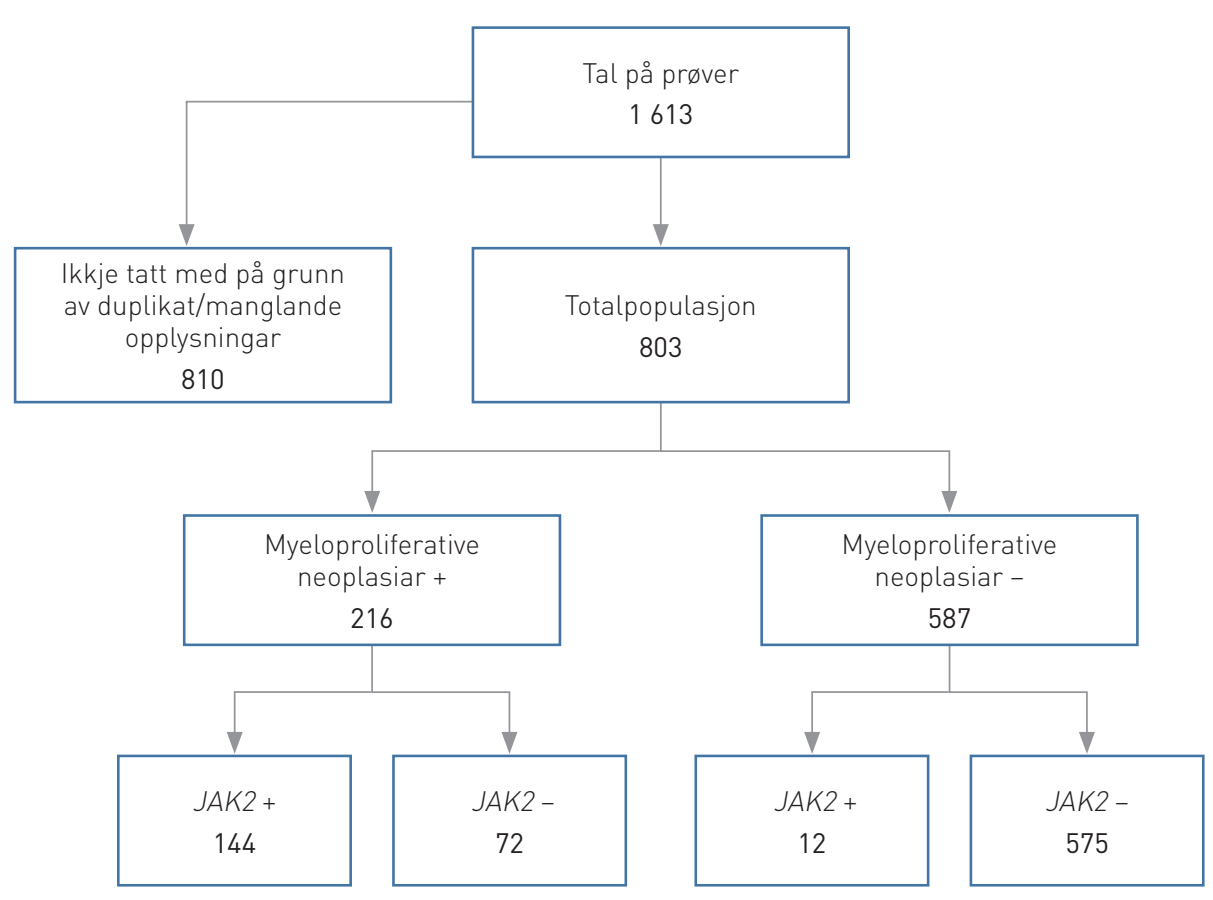

Figur 2 Oversikt over pasientpopulasjonen, påvist/ikkje-påvist myeloproliferativ neoplasi og JAK2-mutasjonsstatus

men det var auka førekomst av transformasjon til meir høggradig malign sjukdom hjå dei med høg allelbyrde samanlikna med dei med låg, høvesvis $13,9 \%$ og $4,0 \%(p=0,046)$.

\section{Diskusjon}

I denne studien har vi sett på førekomst av $J A K 2$-mutasjonen i ei stor pasientkohort undersøkt med spørsmål om myeloproliferativ neoplasi. Rundt ein femdel av pasientane fekk påvist mutasjonen. Dette er ikkje til hinder for at fleire av dei med negativt resultat òg hadde ein myeloproliferativ sjukdom. I tillegg til den klassiske $J A K 2$-mutasjonen, $J A K 2 \mathrm{~V} 617 \mathrm{~F}$, har ein dei siste åra også oppdaga ei rekkje andre mutasjonar som er relatert til desse tilstandane.
I tidlegare studiar har ein funne at mutasjon i ekson 12 av JAK2-genet finst hjå om lag $3 \%$ av pasientane med polycythaemia vera (18), mens mutasjonar i genet som kodar for trombopoietinreseptor (MPL) (19) finst hjå om lag 3\% av dei med essensiell trombocytose og hjå $10 \%$ av dei med primær myelofibrose. Status før 2013 var like fullt at det ikkje var identifisert nokon årsaksforklaring for $30-45 \%$ av pasientane med essensiell trombocytose og primær myelofibrose. Ved bruk av eksomsekvensering fann to forskingsgrupper dette året somatiske mutasjonar i CALR-genet hjå $25-35 \%$ av desse pasientane $(20,21)$.

På grunn av desse resultata kan ein i dag difor forklare inntil $97 \%$ av alle tilfelle av

JAK2V617F-positiv

JAK2V617F-negativ

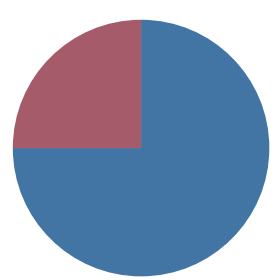

Polycythaemia vera ( $n=108)$

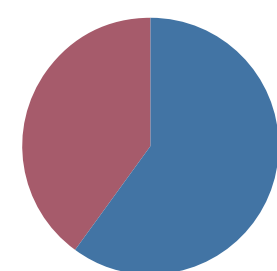

Essensiell trombocytose $(n=92)$

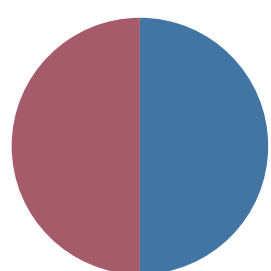

Primær myelofibrose ( $n=16$ )

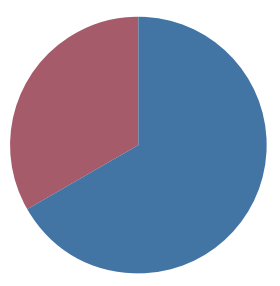

Totalt $(n=216)$
Figur 3 JAK2-mutasjonsstatus hos pasientar med myeloproliferativ neoplasi. Fordeling av JAK2-mutasjonspositive pasientar med polycythaemia vera (81 av 108; 75,0\%), essensiell trombocytose (55 av 92; 59,8\%), primær myelofibrose ( 8 av 16; 50,0\%) og alle med påvist myeloproliferativ neoplasi (144 av 216; 66,7\%) 
Tabell 1 Skilnader i hematologiske variablar og alder for JAK2V617F-positive og JAK2V617F-negative pasientar med polycythaemia vera og essensiell trombocytose. P-verdiar gitt ut ifrå t-test (tosidig). Frekvensen varierer mykje grunna manglande pasientopplysningar

\begin{tabular}{|c|c|c|c|c|c|c|c|c|c|c|}
\hline & \multicolumn{2}{|c|}{$\begin{array}{l}\text { Polycythaemia vera, } \\
\text { JAK2V617F-positiv }\end{array}$} & \multicolumn{2}{|c|}{$\begin{array}{l}\text { Polycythaemia vera, } \\
\text { JAK2V617F-negativ }\end{array}$} & \multirow[b]{2}{*}{ P-verdi } & \multicolumn{2}{|c|}{$\begin{array}{c}\text { Essentiell } \\
\text { trombocytose, } \\
\text { JAK2V617F-positiv }\end{array}$} & \multicolumn{2}{|c|}{$\begin{array}{c}\text { Essentiell } \\
\text { trombocytose, } \\
\text { JAK2V617F-negativ }\end{array}$} & \multirow[b]{2}{*}{ P-verd } \\
\hline & $\begin{array}{l}\text { Gjennom- } \\
\text { snitt (SD) }\end{array}$ & Tal & $\begin{array}{l}\text { Gjennom- } \\
\text { snitt (SD) }\end{array}$ & Tal & & $\begin{array}{l}\text { Gjennom- } \\
\text { snitt (SD) }\end{array}$ & Tal & $\begin{array}{l}\text { Gjennom- } \\
\text { snitt (SD) }\end{array}$ & Tal & \\
\hline Hemoglobin (g/100 ml) & $17,0(2,5)$ & 65 & $17,5(1,6)$ & 18 & 0,43 & $14,4(1,6)$ & 48 & $13,1(1,3)$ & 34 & $<0,01$ \\
\hline EVF & $0,54(0,08)$ & 54 & $0,52(0,05)$ & 14 & 0,64 & $0,43(0,06)$ & 23 & $0,39(0,04)$ & 24 & 0,01 \\
\hline Leukocyttar (. 10\%/L) & $12,9(7,5)$ & 62 & $8,6(3,1)$ & 17 & 0,02 & $11,8(5,8)$ & 48 & $8,8(3,7)$ & 34 & $<0,01$ \\
\hline Trombocyttar $\left(\cdot 10^{9} / \mathrm{L}\right)$ & $551(290)$ & 63 & 268 (87) & 17 & $<0,01$ & 842 (273) & 50 & 859 (329) & 35 & 0,79 \\
\hline Laktatdehydrogenase (U/l) & 289 (130) & 34 & $198(48)$ & 13 & 0,02 & 235 (73) & 26 & $244(80)$ & 25 & 0,68 \\
\hline Alder (år) & $66,6(15,0)$ & 72 & $55,0(14,8)$ & 23 & $<0,01$ & $66,0(13,8)$ & 51 & $61,3(19,5)$ & 35 & 0,23 \\
\hline
\end{tabular}

myeloproliferativ neoplasi med mutasjonar i $J A K 2-, M P L$ - eller $C A L R$-gena (20). Analyse for mutasjonar i $M P L-$ og $C A L R$-gena er no tilgjengeleg ved Haukeland universitetssjukehus, men eventuelle resultat er ikkje inkludert i denne studien.

Det har vore drøfta om eit alternativt skilje mellom JAK2-mutasjonspositive og JAK2mutasjonsnegative myeloproliferative neoplasier hadde vore ei betre inndeling. Føresetnaden for dette er at mutasjonsnegative har ein distinkt ulik fenotype. Ein har vidare tenkt seg at mutasjonspositiv myeloproliferativ neoplasi fordeler seg langs eit kontinuum etter allelbyrde. Forsøk frå dyremodellar har tidlegare vist at ekspresjonsnivået av
$J A K 2$-mutasjonen er viktig for utvikling av ein bestemt sjukdom $(22,23)$.

Ettersom analyse av JAK2-mutasjonen vart etablert som ein integrert del av utgreiinga av pasientar med mistenkt myeloproliferativ neoplasi (11), skal i utgangspunktet alle som er greidd ut for mistanke om desse tilstandane i Helse Bergen ha fått gjort denne analysen i tidsrommet frå 2006 til februar 2012.

Det er iaugefallande at så mange som $25 \%$ av dei med polycythaemia vera var mutasjonsnegative, då dette avvik frå funn $\mathrm{i}$ internasjonal litteratur, der ein rapporterer $<10 \%(20,24)$. Det er nok lite sannsynleg at diskrepansen skuldast analysemetoden, feil i tidlegare artiklar eller særnorsk epidemiologi. Ei meir sannsynleg forklaring er ein viss grad av overdiagnostisering av polycythaemia vera og at pasientar med andre former for polycytemi har fått denne diagnosen på feil grunnlag.

Generelt er polycytemi ei fellesnemning for tilstandar med forhøga hematokrit, og ein skil mellom absolutte og relative polycytemiar (25). Ved absolutt polycytemi er det patologisk høgt totalt erytrocyttvolum, som ved polycythaemia vera, medan det ved relative polycytemiar er normalt erytrocyttvolum, men likevel høgare hematokrit. Sekundære polycytemiar er absolutte polycytemiar som ofte skuldast hypoksi relatert

Tabell 2 Skilnader i kjønn, røykevanar og påvist venøs og arteriell trombose mellom JAK2V617F-positive og JAK2V617F-negative pasientar med polycythaemia vera og essensiell trombocytose i tal og prosent. P-verdiar gitt ut ifrå khikvadrattest og Fischers eksakte test (tosidig). Frekvensen (n) varierer mykje grunna manglande pasientopplysningar

\begin{tabular}{|c|c|c|c|c|c|c|c|c|}
\hline \multirow[b]{2}{*}{ Variabel } & \multicolumn{3}{|c|}{ Polycythaemia vera } & \multirow[b]{2}{*}{ P-verdi } & \multicolumn{3}{|c|}{ Essensiell trombocytose } & \multirow[b]{2}{*}{ P-verdi } \\
\hline & JAK2V61 & 17F-positiv & JAK2V617F-negativ & & JAK2V6 & 7F-positiv & JAK2V617F-negativ & \\
\hline Kjønn & & & & 0,12 & & & & 0,16 \\
\hline Mann & 34 & (42) & $16 \quad(59)$ & & 16 & (29) & $16 \quad(43)$ & \\
\hline Kvinne & 47 & (58) & $11(41)$ & & 39 & (71) & $21 \quad(57)$ & \\
\hline Røyking & & & & 0,01 & & & & 0,31 \\
\hline $\mathrm{Ja}$ & 23 & (38) & $17 \quad(68)$ & & 26 & (55) & $14 \quad(44)$ & \\
\hline $\mathrm{Nei}$ & 38 & (62) & $8 \quad(32)$ & & 21 & (44) & $18 \quad(56)$ & \\
\hline Trombose & & & & 0,55 & & & & 0,10 \\
\hline Ingen & 34 & (42) & 11 (41) & & 22 & (41) & $21 \quad(57)$ & \\
\hline Arteriell & 33 & $(41)$ & 11 (41) & & 27 & (51) & 13 (35) & \\
\hline Venøs & 6 & (7) & $4 \quad(15)$ & & 1 & (2) & (8) & \\
\hline Arteriell og venøs & 8 & (10) & $1 \quad(4)$ & & 3 & (6) & 0 & \\
\hline
\end{tabular}


til underliggjande hjarte- og lungesjukdom. Relativ polycytemi er assosiert med røyking, og storrøyking kan vere årsak til sekundær polycytemi (25).

Noko som støttar opp om at det har vore ein viss grad av overdiagnostisering, er ein nesten dobbelt så høg frekvens av røyking hjå dei med $J A K 2$-mutasjonsnegativ polycythaemia vera ( $38 \%$ mot $68 \%$ ) samt lågare grad av leuko- eller trombocytose i gruppa som er $J A K 2$-mutasjonsnegativ. Pasientar med polycythaemia vera har i motsetnad til dei med ei anna form for polycytemi ofte også ein viss grad av trombocytose og leukocytose (24). Dei som er positive for JAK2ekson 12-mutasjon, har derimot ofte isolert erytrocytose $(18,26)$.

I tillegg kjem at PCR-analysene gjort $\mathrm{i}$ den første tidsperioden (2006-08) hadde høgare deteksjongrense for $J A K 2$-mutasjonen (17), noko som kan ha ført til at nokre pasientar med låg allelbyrde fram til 2008 ikkje vart klassifiserte som JAK2-mutasjonspositive. Øvrige avgrensingar som ligg i studien er at diagnosen som er sett, er vurdert ut frå skjønet til behandlande lege og ikkje er prøvd nærare.

For essensiell trombocytose har tidlegare forsking vist høgare hemoglobinnivå, redusert nivå av erytropoietin og auka leukocyttar for $J A K 2$-mutasjonspositive pasientar enn hjå $C A L R$-positive (27). I vår pasientkohort er ikkje $M P L$ - eller $C A L R$-mutasjonar undersøkt, men ein reknar med at ein stor del av $J A K 2$-mutasjonsnegative pasientar med essensiell trombocytose og primær myelofibrose vil vere positive for desse markørane. Våre data viser signifikant elevert nivå for hemoglobin, hematokrit og leukocyttar hos den JAK2-mutasjonspositive pasientkohorten. Dette er i tråd med oppfatninga at $J A K 2$ V617F-mutasjonen er relatert til ein meir aggressiv undergruppe av essensiell trombocytose enn andre mutasjonar (28).

$J A K 2$-mutasjonen har sidan 2005 vist seg å vere ein viktig markør i diagnostiseringa av myeloproliferative neoplasier. Dei tidligare WHO-diagnosekriteria omfatta ikkje $M P L$ eller $C A L R$-mutasjonar (12), men dei er no innlemma $\mathrm{i}$ den nye WHO-klassifiseringa $(24,29)$ og implementert i diagnosekriteria i det nasjonale handlingsprogrammet med retningslinjer for diagnostikk, behandling og oppfølging av maligne blodsjukdomar (30). Monitorering av $J A K 2$-mutasjonsallelbyrde kan òg vere indisert etter allogen beinmargstransplantasjon for primær myelofibrose og vil i framtida også kunne spele ei rolle ved å identifisere pasientar med auka risiko for tilbakefall $(4,31)$.

$J A K 2 \mathrm{~V} 617 \mathrm{~F}$-analysar er saman med andre mutasjonsanalysar - for $J A K 2$ ekson $12, M P L$ og $C A L R$ - sentrale markørar i utgreiingsbeidet for pasientar der det er mistanke om myeloproliferative neoplasier. Vi har i studien vår vist at det sannsynlegvis har vore ei overdiagnostisering av polycythaemia vera, slik at ikkje alle som tidligare har fått ein slik diagnose ville oppfylt dagens kriterier. JAK2-mutasjonspositive myeloproliferative neoplasier har ulike kliniske trekk som skil dei frå dei mutasjonsnegative, og det er mulig framtidig risikoklassifisering og behandlingsalgoritmar vil ta omsyn til dette.

Forfattarane har fått støtte til forskinga frå Helse Vest, Kreftforeningen, Caroline Musæus Aarsvolds fond og Eivind Møllbach Pedersens fond.

\section{Henry Almedal (f. 1989)}

er medisinstudent.

Forfattaren har fylt ut ICMJE-skjemaet og oppgjev ingen interessekonfliktar

\section{Marta Vorland (f. 1973)}

har ein ph.d.-grad i molekylærbiologi. Ho er medlem av Management Committee for COST Action BM 0902 Network of experts in the diagnosis of myeloproliferative disorders (MPD)/ MPN\&MPNr-EuroNet.

Forfattaren har fylt ut ICMJE-skjemaet og oppgjev ingen interessekonfliktar

\section{Aasne K. Aarsand (f. 1973)}

er ph.d., overlege og spesialist i medisinsk biokjemi. Ho er medlem av Management Committee for COST Action BM 0902 Network of experts in the diagnosis of myeloproliferative disorders (MPD)/ MPN\&MPNr-EuroNet. Forfattaren har fylt ut ICMJE-skjemaet og oppgjev ingen interessekonfliktar

\section{Ida-Sofie Grønningsæter (f. 1985)}

er lege og ph.d.-stipendiat.

Forfattaren har fylt ut ICMJE-skjemaet og oppgjev ingen interessekonfliktar

\section{Øystein Bruserud (f. 1955)}

er overlege, dr.med. og professor i hematologi. Han har lang forskingserfaring, i hovudsak knytta til myeloide malignitetar. Han er med i arbeidsgruppa som har utforma og revidert det nasjonale handlingsprogrammet for hematologiske malignitetar

Forfattaren har fylt ut ICMJE-skjemaet og oppgjev ingen interessekonfliktar

\section{Håkon Reikvam (f. 1978)}

er ph.d. og lege i spesialisering i indremedisin og hematologi.

Forfattaren har fylt ut ICMJE-skjemaet og oppgjev ingen interessekonfliktar

\section{Litteratur}

1. Mehta J, Wang H, Iqbal SU et al. Epidemiology of myeloproliferative neoplasms in the United States. Leuk Lymphoma 2014: 55: 595-600.

2. Titmarsh GJ, Duncombe AS, McMullin MF et al.
How common are myeloproliferative neoplasms? A systematic review and meta-analysis. Am J Hematol 2014: 89: 581 - 7

3. Anderson LA, McMullin MF. Epidemiology of MPN what do we know? Curr Hematol Malig Rep 2014 9: $340-9$.

4. Ghanima W, Knutsen H, Delabie J et al. Primær myelofibrose - patogenese, diagnostikk og behandling. Tidsskr Nor Legeforen 2013; 133 1946-50.

5. Rampal R, Mascarenhas J. Pathogenesis and management of acute myeloid leukemia that has evolved from a myeloproliferative neoplasm. Curr Opin Hematol 2014; $21: 65-71$

6. James C, Ugo V, Le Couédic JP et al. A unique clonal JAK2 mutation leading to constitutive signalling causes polycythaemia vera. Nature 2005; 434: 1144-8

7. Baxter EJ, Scott LM, Campbell PJ et al. Acquired mutation of the tyrosine kinase JAK2 in human myeloproliferative disorders. Lancet 2005; 365 1054-61

8. Levine RL, Wadleigh M, Cools J et al. Activating mutation in the tyrosine kinase JAK2 in polycythemia vera, essential thrombocythemia, and myeloid metaplasia with myelofibrosis. Cancer Cell 2005; 7: 387-97.

9. Kralovics R, Passamonti F, Buser AS et al. A gainof-function mutation of JAK2 in myeloproliferative disorders. N Engl J Med 2005; 352: 1779-90.

10. Reikvam H, Nepstad I, Tamburini J. Predicting effects of kinase inhibitor in therapy for myeloid malignancies - the challenges in capturing disease heterogeneity. Expert Opin Investig Drugs 2013: 22: $1365-70$.

11. Tefferi A. Novel mutations and their functional and clinical relevance in myeloproliferative neoplasms: JAK2, MPL, TET2, ASXL1, CBL, IDH and IKZF1. Leukemia 2010: 24: 1128-38

12. WHO. World Health Organization Classification of Tumors of Haematopoietic and Lymphoid Tissues. 4. utg. Lyon: International Agency for Cancer, 2008.

13. Spivak JL, Considine M, Williams DM et al. Two clinical phenotypes in polycythemia vera. N Engl J Med 2014; 371: 808-17.

14. Kiladjian JJ. The spectrum of JAK2-positive myeloproliferative neoplasms. Hematology Am Soc Hematol Educ Program 2012; 2012: 561-6.

15. Reikvam H, Tiu RV. Venous thromboembolism in patients with essential thrombocythemia and polycythemia vera. Leukemia 2012; 26: 563-71.

16. Larsen TS, Christensen JH, Hasselbalch $\mathrm{HC}$ et al. The JAK2 V617F mutation involves B- and T-lymphocyte lineages in a subgroup of patients with Philadelphia-chromosome negative chronic myeloproliferative disorders. Br J Haematol 2007; 136 : 745-51.

17. Jones AV, Kreil S, Zoi K et al. Widespread occurrence of the JAK2 V617F mutation in chronic myeloproliferative disorders. Blood 2005; 106: 2162-8.

18. Scott LM, Tong W, Levine RL et al. JAK2 exon 12 mutations in polycythemia vera and idiopathic erythrocytosis. N Engl J Med 2007: 356: 459-68.

19. Pikman Y, Lee BH, Mercher T et al. MPLW515L is a novel somatic activating mutation in myelofibrosis with myeloid metaplasia. PLoS Med 2006; 3: e270.

20. Nangalia J, Massie CE, Baxter EJ et al. Somatic CALR mutations in myeloproliferative neoplasms with nonmutated JAK2. N Engl J Med 2013; 369: 2391-405.

21. Klampfl T, Gisslinger $H$, Harutyunyan AS et al. Somatic mutations of calreticulin in myeloproliferative neoplasms. N Engl J Med 2013; 369: 2379-90.

22. Lacout C, Pisani DF, Tulliez M et al. JAK2V617F expression in murine hematopoietic cells leads to MPD mimicking human PV with secondary myelofibrosis. Blood 2006: 108: 1652-60.

23. Geetha JP, Arathi CA, Shalini M et al. JAK2 Negative Polycythemia Vera. J Lab Physicians 2010; 2: $114-6$.

24. Barbui T, Thiele J, Vannucchi AM et al. Rationale for revision and proposed changes of the WHO diagnostic criteria for polycythemia vera, essentia thrombocythemia and primary myelofibrosis. Blood Cancer J 2015: 5: e337. 


\section{ORIGINALARTIKKEL}

25. Berentsen S. Sekundære og relative polycytemier: Indikasjon for venesectio? Indremedisineren 2015; 1: 16-9.

26. Pietra D, Li S, Brisci A et al. Somatic mutations of JAK2 exon 12 in patients with JAK2 (V617F)negative myeloproliferative disorders. Blood 2008; 111: 1686-9.

27. Rotunno G, Mannarelli C, Guglielmelli P et al. Impact of calreticulin mutations on clinical and hematological phenotype and outcome in essential thrombocythemia. Blood 2014; 123: 1552-5.

28. Rumi E, Pietra D, Ferretti V et al. JAK2 or CALR mutation status defines subtypes of essential thrombocythemia with substantially different clinical course and outcomes. Blood 2014; 123: 1544-51.

29. Arber DA, Orazi A, Hasserjian R et al. The 2016 revision to the World Health Organization classification of myeloid neoplasms and acute leukemia. Blood 2016; 127: 2391-405.

30. Helsedirektoratet. Nasjonalt handlingsprogram med retningslinjer for diagnostikk, behandling og oppfølging av maligne blodsykdommer. http://legeforeningenno/Fagmed/Norsk-selskapfor-hematologi/Handlingsprogrammer/ (12.9.2016)

31. Borowczyk M. Wojtaszewska M, Lewandowski K et al. The JAK2 V617F mutational status and allele burden may be related with the risk of venous thromboembolic events in patients with Philadelphia-negative myeloproliferative neoplasms. Thromb Res 2015; 135: 272-80.

Motteke 10.2. 2016, første revisjon sendt inn 1.6. 2016, godkjent 12.9. 2016. Redaktør: Ragnhild Ørstavik. 